\title{
Models of Green Parks and Public Lighting Systems of Several Advanced Cities in the World: Visionary Recommendations For Ho Chi Minh City
}

\section{Phan Thi Hong Xuan}

Faculty of Urban Studies, 10 -12 Dinh Tien Hoang, Ben Nghe Ward, District 1, University of Social Sciences and Humanities, Vietnam National University - Ho Chi Minh City, Vietnam.

\section{ARTICLE INFO}

Article history

RECEIVED: 09-Sep-19

REVISED: 07-Oct-19

ACCEPTED: 04-Dec-19

PUBLISHED: $16-$ Dec-19

*Corresponding Author:

Email:xuan.pth@hcmussh.edu.vn

\begin{abstract}
Cited from several experienced lessons from advanced nations all over the world, this paper proposes suggestions to upgrade, repair, and replace the green park model of Ho Chi Minh city by saving electrical power lighting systems that are environmentally friendly towards a Green-CleanBeautiful Ho Chi Minh city in the future.
\end{abstract}

Keywords: green-park, public lighting, developed, Ho Chi Minh City, environmentally-friendly world.

\section{Introduction}

We live in the twenty-first century; an age of urbanization and globalization. In an age where humanity must face many challenges to search for the solutions of big changes and to answer the question: In what way can we grasp the opportunities of modern science and technology, of the Artificial Intelligence while minimizing the risks to our natural and social environments.

According to estimates in 2018 , urban areas in the world account for about two-thirds energy consumption and $70 \%$ of gas emissions that cause a rise in the Earth's temperature, breeding climate change [15]. Data from the Global Green Growth Institute (GGGI) shows that more than half of the 7 billion people in the world are currently living in urban areas. It is predicted that by 2050, this number will have increased to 6.5 billion people, accounting for two-thirds of the human population.

The rapid rise of urban areas in developing countries, along with the growing number of migrants from rural to urban areas, has led to the explosion of megacities. In 1990, there were only ten cities across the world with more than 10 million people, but in 2014, the number of megacities reached 28 with 453 million people; more than half of the world's population live in urban areas. Urbanites often suffer from health problems such as breathing difficulty, sedentary lifestyle, alarmingly high rates of obesity, cardiovascular disease and many other diseases such as poor mental health, increasing stress levels. These unhealthy trends warant the need for solutions that contribute to building spiritual lives for the people through the implementation of sustainable models towards a healthy urban lifestyle.

Currently, in addition to the trend of urban development following the model of 'smart city' and 5.0 society, several developed countries in the world have been promoting the model of an ecological city, green city, green belt, green area, green office and green school, green villa, green factory and so on. So, what are eco-city and green city? Why is it necessary to study the model of green parks and lighting systems of advanced cities in the world? In this article, we try to draw some lessons from countries around the world about the problems that are being discussed with the hope that Ho Chi Minh City can refer and implement appropriate solutions. This can help realize the objectives of the Construction Resolution of Ho Chi Minh City, to build the city into a modern-civilized-sentimental city with good quality of life.

\section{Ecological city, green city is one of the world's current sustainable development trends}

Cities in the twenty-first century aim at sustainable development that focus on preserving the natural world 
in the artificial environment. Building a safe and sustainable urban area means ensuring that people have access to adequate, safe and affordable housing and upgrading slums, neighborhoods and the urban fringe. The concept of "Sustainable Urban Development" was initially mentioned in the United Nations General Assembly in December 1983. In 1991, the concept of sustainable urban development was officially adopted as follows: "Sustainable urban development highlights the need for reform of market mechanisms to achieve environmental goals and the achievement of a balance with social and economic considerations." [16].

Being the 2019 Association of Southeast Asian Nations's (ASEAN) rotating president, Thailand has launched the slogan "Strengthening Partnerships for Sustainability" to promote "Stability of Things". This shows the determination and effort that the ASEAN countries, including Vietnam, are putting into the implementation of the Millennium Development Goals. Mr. Don Pramudwinai - current Minister of Foreign Affairs of the Kingdom of Thailand, in his speech (Provided by Royal Thai Consulate-General), emphasizes that: Sustainable development is an overarching concept that is directly related to "Sustainability of things". However, the first aspect of sustainability that usually comes to the mind of the public is environmental sustainability, which is a significant component of the concept and part of the United Nations 2030 Agenda for Sustainable Development and its Sustainable Development Goals (SDGs).

It is undeniable that the future of humanity lies in cities. Sustainable cities can be an important factor for a country to be able to flourish in the global economy. The terms eco-city, green city, and garden city are increasingly mentioned in both developed and developing countries.

The concept of eco-city originated from the 1980s and was first presented to the public by German scholars. Giving birth to the "Eco-city" movement was Richard Register, an internationally recognized expert. He founded Urban Ecology in Berkeley (USA) in 1975. Over the years, the movement of building green cities and ecological cities has developed rapidly all over the world.

According to the Global Green Growth Institute (GGGI), "Green city" is an urban area that navigates its ways towards long-term goals for environmental protection, creating social inclusion and developing a sustainable economy. Green city development is a process in which cities consume resources more efficiently, become more resilient to withstand climate change, reduce carbon emission, create social inclusion and more social justice.
Green city, "Eco-city" is built on the principle of taking the environment as the foundation of development, minimizing carbon emission, using renewable energy and integrating environmental factors (green trees, surface water, natural ecosystems) into urban activities. Economic growth, poverty reduction, increasing population density, improving habitat quality, is an urban trend of adapting and mitigating climate change.

According to the Australian Research Centre for Urban Ecology, "An Eco-city is a city where landscape and built form are balanced". More specifically, ecological cities enable their residents to live a high quality of life while using minimal natural resources. In Richard Register's vision of ecological cities, sprawling, low-density cities are transformed into networks of high and medium density urban settlements of limited size separated by green space, with most people living within walking or cycling distance of their workplace [1].

In European countries, green cities must ensure factors such as green space - urban areas with a high density of trees, high ratio of trees per person, and public space for people; green buildings - use of environmentally friendly, energy-saving materials; green transport - prioritize public transport using recycled gas. This also includes investment into public transportation, creating public green space, preserving historical and cultural landscapes, famous sights, environmentally-friendly sights, improving the planning and management of urban areas with the help of the residential community thereby also creating social inclusion.

In developing countries, the process of industrialization, urbanization, and modernization often takes place at the same time due to the direct development of obsolete socio-economic forms into modern forms that can integrate into the global economy under the pressure of globalization. To solve urban environmental problems in such a complex context for developing countries, ecological urban planning is an appropriate solution. This is a solution oriented planning, which applies the latest knowledge and experience of developed countries to directly form a modern city without encountering the problems of widespread industrialization and urbanization during the process [1].

By the end of 2017, Ho Chi Minh City announced the Scheme of "Developing Ho Chi Minh City into a smart city in the period of 2017-2020, with a vision to 2025". This did not mean that the city government did not care about sustainable development and environmental protection. For instance: in March 2019 HCMC People's 
Committee and the Ministry of Foreign Affairs launched the campaign "Clean up plastic waste day in 2019", with the desire to deploy the spirit of the G7 summit, to raise people's awareness and call for practical actions for environmental protection. It is clear that the human desire to conquer nature since the very beginning, has now gradually shifted to a gentle attitude looking for harmony in nature. "Governments have launched many campaigns in the world such as movements of planting trees, walking, jogging, and movements/bans against plastic waste, etc.

The University of Social Sciences and Humanities, VNU$\mathrm{HCM}$, launched the Green University program, inaugurating the USSH's garden on 11 May 2019, proving the National University of Ho Chi Minh City's spirit of innovation. Ho Chi Minh City has built a smart and creative city under the guidelines of the city government, which is also a global development trend. Green University is an initiative of sustainable development that needs to be strongly promoted.

Summary: The terms green city and ecological city refer to the urban planning and construction solutions with the purpose of reaching $60-70 \%$ green space coverage in an urban area. These are cities with a harmonious distribution between people, nature and architectural landscape. In other words, the first criterion of forming an ecological city is planing urban land use in order to guarantee the harmony between technical and social infrastructure, "green" space and "surface water".

\section{Assessment criteria for an Eco-city in the world}

International Eco-city Standard (IES) is an assemblage from a group of eco-city builders coming from organizations all over the world. IES not only estimates the status and progress of a city's new development to become an eco-city but it also mentors the completion level on distinct models from subareas to regional areas which are based on principles of ecological health systems and designs.

Criteria for judging an eco-city followed by IES, include:

- City structure: land usage and urban architectures

- Urban traffic with priority orders: pedestrian lines, bike lanes, elevators, escalators, public transportation like buses, and electric vehicles or subway train.

- Energy: using renewable energy such as wind energy, solar energy, etc., restricting the use of non-renewable resources, using energy conservation solutions.
- Society: responding to social requirements through architecture and designing accommodation for residents, ensuring spaces for education, recreation, etc.

In Vietnam, a circular from the ministry of construction, No: 01/2018/TT- BXD, Ha Noi 5th January 2018 about "Regulations on targets of building green growth cities" stated the following:

-Green growth city: is a city that gains economic growth and improvement through regulations on city activities in order to restrain the effect of unfavorable impacts on the environment and natural resources.

-Building green growth city: is constructing, planning urban activities; setting up and implementing developing urban programs; investing in urban development towards green growth city.

The aforementioned circular brought about the following priority activities to implement building green growth city: developing environmentally friendly green construction; applying green building materials and technology; using energy economically and effectively, encouraging the use of clean energy; building ecologically green smart cities.

\section{Models of green parks in several cities and countries in the world.}

\section{Singapore}

According to "Memoirs of Lee Kuan Yew: From Third World to First", the former prime minister Lee Kuan Yew shared about the national transforming of Singapore from a cultivation land to a green, urban civilization. Planting process must be conducted by researching and adapting to natural conditions through Singapore's studies about land status. This country is located within the belt of equatorial tropical rainforest with intense sunlight (intense heat from the sun) and heavy rain throughout the year that leads to the forest tree devastation, heavy rains erode the topsoil and wash away the ground nutrients. In order to create mass grass plots, people usually exploit the features of the blend of anti-erosion fertilizer and use lime to solve the acidic soil.

Singapore has become a country with high coverage of greenery by designing green streets, green condominiums, green corridors or bridges fully covered by vine plants. Singapore aims at urban planning in the direction of reducing environmental pollution in the streets with many trees, 
mixing trees along streets in high-rise buildings close to each other. The Singapore government has implemented the strategy of 'garden in the city, bulb gardens, green wall gardens, gardens anywhere', an important element in environmental landscape planning when trees are highly prioritized. Not only that, but urban plans also aim at the thematic plant routes. These are wide green interlocking canopy roads that create green coverage, or alternating bougainvillea pathways as a highlight for tourism.

As a small country, Singapore has always effectively exploited resources to avoid waste, focusing on greenery to increase air circulation and reduce dust for vehicles. Singapore also aims to take advantage of the construction of large parks that function as the lungs of the city. Typically, Garden by The Bay is a green park with diverse ecosystems and plentiful landscapes, highlighted with a huge super-energy tree system and thousands of tropical plants, which are effective tourist spots.

Under the name of the most beautiful airport in the world, Singapore Changi Airport hosts a plentiful variety of biological garden systems with a multitude of different plants. Each terminal displays distinct plant landscape, providing passengers with calming green spaces within the airport instead of unoriginal transit areas.

\section{Malaysia}

Malaysia is naturally bestowed with greenery. With three-quarters of its land as forest area its planning and development is always consistent with ecological urban construction and smart ecology.

In the Great Kuala Lumpur 2010 plan, the Malaysian government decided to transform Kuala Lumpur into one in 20 worth-living cities with the highest economic growth rate in the world. Malaysia is extremely interested in the goal of "green development", strengthening the city's tree system, expanding green lungs and re-creating a clean-living environment. Malaysia is determined to plant 100,000 trees and $45 \mathrm{~km}$ of trees for walking paths, thus linking symbolic and scenic buildings.

Along with Kuala Lumpur, Malaysia also expanded, developing Putrajaya as a new age city - Southeast Asia's most intelligent and modern administrative center of the country. Putrajaya is now known as a city with a young, modern and civilized aesthetic in organizing human life, advanced technology and improving the environment. The Malaysian government focuses on building a smart, green, clean and beautiful city with clean air, replacing
Kuala Lumpur's crowded image. Taking the green city image as a priority, Putrajaya uses $40 \%$ of the area for parks, lakes, and marshes and creates a "city in jungle" image.

In recent years, a Malaysian project called Forest City located in Johor Baru state has attracted the attention of the international community. Forest City project is a beach encroaching city of Country Garden Group. Forest City is known as Asia's smart eco-city project with links between infrastructure, services, and unlimited people. The green areas are formed vertically, giving the place a natural environment. The modern transportation system is soundproof, dustproof and possessing unique space for traveling without a vehicle across the city. In addition, Forest City has elevated walking gardens, aerial gardens, and artificial rain systems. When completed, the city will be operated by the technology of artificial intelligence. The city's use of greenery and artificial intelligence are two pivotal characteristics that make it unique to Malaysia [3]

\section{Japan}

Japan is one of the most developed countries with sustainable navigation and combines development with environmental protection. In order to limit urban expansion and focus on sustainable urban development, the Japanese government has set up plans to build urban systems that divide regions and harmonize with the environment. So far Japan has made remarkable achievements in building a model of smart urban, green and ecological cities. Japanese cities aim to develop and reduce the amount of carbon emitted by many actions such as pollution control, calling for reductions in gas, reducing dependence on fossil fuels by establishing frameworks. This is suitable for renewable energy, energy conservation technology, and transportation system.

The particular case to look at is in the outskirts of Kanazawa, near the Japanese city of Yokohama. In the process of planning this residential area, the project focuses on building a system of greenery covering residential areas and roads.

\section{The importance and the role of green space in urban life and the development of cities and the experience of some cities in the world}

In sustainable urban development, directly proportional distribution of green space according to a balanced 
distribution of the population is one of the fundamental principles. Urban green space plays a pivotal role in helping to enhance urban appearance, and contributes to urban physical development, maintenance and balance of the urban environment and air pollution reduction. Urban green space contributes to the physical and mental health of the people to escape the stresses of modern life, enhances community cohesion, social interaction, reduces aggressive behavior, reduces fear levels and promotes better neighborly relations.

There are many famous green constructions in the world such as the circular suburbs on the outskirts of Copenhagen, the capital city of Denmark, known as the greenest city on the planet. Stockholm, the capital city of Sweden is dubbed the "green capital of Europe" where more than $30 \%$ of the area in the city is a canal and another $30 \%$ is green parks. In Britain, The Mayor of London, Sadiq Khan, announced a budget of over $£ 6$ million in grant funding for green space improvements, as part of his push to make London the world's first National Park City. The Mayor also set a goal of turning the capital up to $50 \%$ green by 2050 . The "National Park City" plan of the Mayor of London includes the improvements of the London Plan's policies in order to protect the green spaces and create new open spaces, especially in areas that have the least access to parks. This program will also help identify and promote the economic value of green infrastructure in London.

Going back to the development of Vietnam in general and Ho Chi Minh City in particular, we cannot apply stereotypes based on the model of the advanced countries aforementioned because there are still many shortcomings in economic, political and infrastructural concerns. According to M. Arch, Pham Hoang Phuong (National Institute of Architecture - Ministry of Construction) "We should not be too self-deprecating, but it will also be a pipe dream to assume that the future will have absolute green buildings. For the nature of construction activities is to improve the environment, it will certainly affect the environment, though much less. Green solutions only help minimize it but still prove difficult to thoroughly achieve. Do not just blindly follow the concept of general architecture that is beautiful and unusual but ignores other core values of urban life. Green architecture in Vietnam can only become known and useful to the people if it immediately meets the needs of the low-income and middle-income population. Vietnam needs to become a green architecture development point from its own needs and internal forces. It is time to identify and understand the gains and losses in the green architecture game to fully ascertain a green architecture development orientation in Vietnam, avoiding the long-term waste and negative impacts, contributing to the development of industrialization and modernization of the country" [13].

Agreeing with the above view, we believe that it should start with small actions but have a practical impact on each individual's concept in order to spread to the whole community. Korea is a country with small but effective initiatives such as Korea's green growth policies to encourage people to plant and protect trees. In March 2015, about 1,220 Korean people hugged a forest of trees for more than one minute in Korea to express their love for trees and raise public awareness of tree protection in the community. Earlier in 2013, 936 people from Portland city, Oregon (USA) simultaneously hugged trees for one minute and set up the first Guinness World Record for the most people hugging trees. Such evidence presented does not mean that we also must call for the people to engage in the tree-hugging movement, since it depends on the cultural characteristics, climate, and ecology of each country that launches the campaign accordingly. On the positive side, there are many aspects and ways to mobilize urbanites to understand the importance of planting and nurturing trees in the living space. Ho Chi Minh City has the right to hope for a green and ecological urban area because even South Korea in the previous industrial development period had been described by the term "black growth" for its destruction of the environment, the birth of industrial centers such as Seoul and Ulsan, the appearance of dead rivers and a sky covered by dust and smoke. But after many years, there is a greater awareness of the importance of environmental protection, and this is widely acknowledged through the government's policies that promote "green growth", erasing the previous dark period and replacing it by the word "green". In Ho Chi Minh City, the government needs to have action programs to encourage people to plant trees in their own houses, office environments, buildings, community service centers, etc., especially fast-growing trees that are easy to grow. This can be easily implemented because each tree will have different characteristics for feng shui of each place, each individual use. Asians are very fond of Feng Shui urbanites can be encouraged in this way. [4].

Experience from Singapore: The Singapore government chose a date in the first week of November as the National Tree Planting Day. In addition, large buildings are required to have space to house a specific number of trees in order to be granted construction permits. Furthermore, according to NParks Regulations, trees in high traffic sites, such as expressways and major roads, are inspected once every 12 months 
The city of Vancouver, Canada comes to realize the objectives of Urban Agriculture Program is to comprehensively manage urban trees, to make an extremely valuable contribution to the well-being of its citizens, as well as making sure that the pressure of the need for trees for urban development will not come up. At the same time, we need to search for a certified arborist company (ISA Certified Arborist credential) to ensure proper maintenance, reduce future needs and maintenance cost.

Experience from Japan shows that: Under the Regulations, tree maintenance works such as insect prevention and pruning should be conducted regularly, and that dead or decayed trees should be removed as soon as possible. Tree Management Regulations in Tokyo provided a legal basis for specific management strategies. The content of the regulations in Tokyo provides a legal basis for tree management strategies. They provide a clear delineation of responsibilities among different parties to ensure proper and effective tree management on both government and private land.

\section{Developing lighting systems for smart cities, implementing IOT technology (Internet of Things) on street lighting management system}

The city is a densely populated, non-agricultural, central area of territory. It houses many large and small spaces to meet the needs of people and perform the functions of each area. Human living space has a very broad definition, including man-made structures ranging from large spaces in urban areas to smaller spaces such as houses and apartments [17]. Urban space consists of urban architectural objects, green trees and water surfaces in urban areas that directly affect the urban landscape [10].

Therefore, the lighting system and urban green space play a very important role in forming and developing a city. The first task is to learn about changes in countries around the world in the management and operation of lighting and green areas. Vancouver, Canada is now one of the greenest cities in the world. This is a notable example of urban planning worth studying by many countries in the world. It is also the most ideal city to live in the world according to The Economist (UK), which is based on criteria like infrastructure, goods, services, safety levels , etc. "Vancouver is highly evaluated in controlling $\mathrm{CO} 2$ emissions and maintaining air quality, thanks to the city's interest in boosting green energy and prioritizing hydropower development. Rows of trees that are combined and used as corridors are sustainable development initiatives for recreational areas, protecting the living environment, public transport, and other amenities. Water pipes, electric wire, bike paths, and walkways are combined with green trees to connect empty spaces for the people. A special feature of sustainable design is the use of sustainable materials, a large amount of recycled concrete and the use of natural green plants to prevent topsoil drifting. Local public transport system is connected to all the adjacent residential areas with open spaces, parks, streets and roads designed for pedestrians, cyclists and public transport [6]. With an existing overview, many countries are moving towards sustainable development, making the service industry environmentally friendly, developing the country and protecting the environment at the same time. The construction of green parks is for the purpose of creating green areas when cities are about to be covered with concrete.

Vancouver is moving towards The Greenest City Action Plan: The Action Plan in 2020 is divided into 10 smaller plans to achieve sustainability such as the Green economy, taking action on climate change, green transportation, green traffic, zero waste, respecting the environment, clean water, full access to nature and local food use. In Vietnam, looking from above, the city is like a sprawling place with untidy blocks of concrete that look very rough, in addition, these concrete blocks are being heated up under the sultry weather of Vietnam, but with the green areas that green park has brought, the city is compensating for it. Not only for its natural attractiveness, but a park is also a central place packed with entertainment activities, as well as the daily routines of the surrounding people. Public spaces and green trees are a measure of the quality of life and creativity.

Currently in Vietnam, the annual electricity consumption for lighting accounts for about $35 \%$ of the total electrical energy consumption. Compared to the world, which is only $16-17 \%$, this is a much higher figure. In particular, the public lighting system installation in our country hasn't brought out the maximum efficiency, partly because it is outdated (installed long ago) and is severely degraded, or using energy-consuming technology, so there is still a lot of electricity wasted during the process. According to the information from HCM city Energy Conservation Center (ECC HCMC), large cities in Vietnam are still using high-pressure Mercury-vapor lamps or Sodium-vapor lamps for public lighting systems (for instance, Ha Noi 52\%, Bac Giang 65\%, Tuyen Quang 100\%, Hoi An 60\%, Ben Tre $83 \%$ and Rach Gia 90\%). This type of lamp has high electricity consumption, low luminous efficacy, a short average life span of only 6000-18000 hours and low quality and performance. The system of lighting control stations is only supervised and controlled via local 
Lighting Control Panel, and there are almost no lighting control devices available for this lighting system [8]. The challenge for localities involved in public lighting networks is to improve the quality of lighting but reduce power consumption and cut annual operating budgets. People see public lighting as a pivotal public service and require an improved quality. Therefore, this is a significant pressure and a problem to be solved for municipal governments.

Currently, in Ho Chi Minh City, controlling and monitoring of public lighting systems is still largely manual. There are many difficulties realted to this such as high time-consumption, high cost, danger. In stormy weather, one is unable to update the operating status or fix damaged equipment on time. Therefore, an intelligent and automatic controlling system is required to effectively manage the time as to when to turn off the light in the period of shortage of electricity.

Transforming HCM City into a smart city and improving the living standards needs group solutions. Visionary models are studied and consulted by experts from many fields. Based on the 17 goals of the United Nations and the specific objectives of Vietnam in general and Ho Chi Minh City in particular, it is necessary to improve the quality of life for the people in many ways by making good use of local advantages, integrating in the nationwide model that are both modern and identical in technology.

\section{Conclusion}

In the National Urban Development Program in the period of 2012-2020, it is emphasized that urban development ensures effective use of construction land fund, investment in synchronous construction of technical and social infrastructure, environmental quality control, harmony between conservation, renovation, and new construction. To build urban areas with good living conditions and enhance regional and international urban competitiveness.

The solutions in the program on policy mechanisms: research and development of green cities to ensure rapid and sustainable urbanization to implement the National Strategy on green growth; on science, technology and environment: formulate policies to encourage the use of new and environmentally friendly construction materials; new technology in housing construction to ensure good quality and low cost for different income objects; study energy-saving solutions in housing, public works and services.
The status of planning in Ho Chi Minh City shows that it has not ensured synchronous green spaces in urban areas linked together by streets with trees and tree rows to form a continuous green system. Nor have all the lakeside land, canals and all possible spaces been used for trees. Not to mention where to plant scientifically and suitably with geography and soil.

In addition to the difficult problem of "urban greening", the construction of high-rise buildings and maintenance of internal activities also means that the state must spend a huge amount of electricity. In advanced countries in the world today, the model of green buildings and ecological buildings has been applied in practice. These buildings are designed according to the "open" concept to take full advantage of nature using materials that absorb less heat; making the lake cool down inside the terrace; enhance the use of solar energy, etc. However, if one compares the feasibility of this for a developing country like Vietnam, the application of ecological urban and green urban models is a long-term process of private change, actions start from individuals to communities.

The term "Smart City" began to appear in 2007 and is widely available in the network of countries around the world, bringing scientific and technological applications into managing and operating society. This condition requires stakeholders in society to constantly innovate, apply smart technology to social activities, make new connections, and apply artificial intelligence. These are factors that promote the formation and development of smart society. The IoT solutions (Internet of Things) provided in the Smart City area addressing issues related to living activities of urban residents including traffic congestion, air pollution, and noise, aiming to help cities safer. Ho Chi Minh City is currently in the construction phase to become a smart city and it should refer to the successful lessons of previous countries, especially the ASEAN countries, here are green parks and smart lighting systems.

\section{Reference}

Aiesec, 2019, 17 mục tiêu phát triển bền vững (17 sustainable development goals), https://aiesec.vn/ muc-tieu-phat-trien-ben-vung/

A.R. Sadeghi, M. Khakzand, M.A. Dehghani1, 2019, Spatial distribution of urban green spaces using entropy model and coefficient of dispersion, International Journal of Human Capital in Urban Management (IJHCUM) Homepage: http:// www.ijhcum.net/ Int. J. Hum. Capital Urban Manage., 4(1): 23-32, Winter 2019, http://www.ijhcum.net/article_34802_fc4166d71cdf496245eeb5ab7054770e.pdf 
Blog Yêu môi trường, Đô thị sinh thái là gì? (What is eco city?) https://yeumoitruong.vn/threads/ do-thi-sinh-thai-la-gi.6501/.

Journal of Architecture, 11/2015, Tăng trưởng xanh: Nhìn từ góc độ Quy hoạch đô thị xanh (đô thị sinh thái) (Green growth: From the perspective of green urban planning (eco-urban) http://www.xaydung.gov.vn/web/guest/trangchi-tiet/-/tin-chi-tiet/Z2jG/86/298613/tang-truong-xanhnhin-tu-goc-do-quy-hoach-do-thi-xanh-do-thi-sinh-thai. html

Hai Linh Tran, 2016, "Xanh hóa châu Á" - Xanh từ lý luận đến thực tiễn (Greening Asia: from Theory to Reality), http:// e4g.org/nhung-cai-gia-cua-chu-xanh-trong-kien-truc/ (The values of the word "Green" in architecture)

Khanh Phuong, 2017, Vancouver - điển hình về quy hoạch đô thị bền vững (Vancouver Green City; Most Sustainable City) https://ashui.com/mag/tuongtac/nhin-ra-the-gioi/13312vancouver-dien-hinh-ve-quy-hoach-do-thi-ben-vung.html

Luu Duc Hai, 2011, Đô thị sinh thái trong phát triển đô thị Việt Nam (The Eco cities in Vietnam's urban development), Journal of Urban planing (No. 05. 2011), https://ashui.com/ mag/chuyenmuc/quy-hoach-do-thi/4945-do-thi-sinh-thaitrong-phat-trien-do-thi-viet-nam.html

Lithaco, http://www.lithaco.com/vi/he-thong-chieu-sangcong- (public lightening system) http://www.lithaco.com/ $\mathrm{vi} /$ he-thong-chieu-sang-cong-cong.html

Manh Quyen, 2018, Tiến tới thành phố xanh và thông minh (For becoming a green and smart city), http://www.sggp.org.vn/ tien-toi-thanh-pho-xanh-va-thong-minh-506112.html

National Assembly of the Socialist Republic of Vietnam, Law 2009 30/2009/QH12 on planning

Nguyen Thanh Lam, 2018, Nhận diện đô thị thông minh (To identify on smart city), https://www.thesaigontimes. vn/272061/nhan-dang-do-thi-thong-minh-.html
Nguyen Phuong, 2018, London quyết trở thành "TP Công viên quốc gia" đầu tiên trên thế giới, (London want to become "the first National Park City in the world) http://kinhtedothi.vn/ondon-quyet-tro-thanh-thanh-pho-cong-vien-quocgia-dau-tien-tren-the-gioi-310686.html

Newspaper online of Natural resources and Enviroment, 2015, Những "chiêu độc" khuyến khích trồng và bảo vệ cây xanh ở Hàn Quốc (These "special tactics" to encourage planting and protecting trees in Korea) https://baotainguyenmoitruong.vn/the-gioi/nhung-quot-chieu-doc-quot-khuyenkhich-trong-va-bao-ve-cay-xanh-o-han-quoc-788147.html

Phan Thi Hong Xuan (2019), TP.HCM trong mạng lưới các thành phố thông minh ASEAN: cơ hội, thách thức và một số giải pháp (giai đoạn 2019 - 2030, định hướng đến năm 2035), Hội thảo quốc tế "TPHCM trong mạng lưới các thành phố thông minh trong ASEAN: cơ hội và thách thức" (Ho Chi Minh City in the ASEAN Smart Cities Network: opportunities, challenges and some solutions (period 2019 - 2030, orientation to 2035), International Conference "HCMC in the network of smart cities in ASEAN: opportunities and challenges ") , NXB ĐHQG - HCM

Pham Hoang Phuong, 2014, Những cái giá của chữ "Xanh" trong kiến trúc (The prices of "Green" in architecture), https://kienviet.net/2014/10/30/ nhung-cai-gia-cua-chu-xanh-trong-kien-truc/

The university of Hongkong, What Is Sustainable Urban Development? http://www.dupad.hku.hk/susurban/ What\%20is\%20Sustainable\%20Urban\%20Development. htm

Tran Thai Nguyen, 2011, Công viên - gợi mở quá khứ... (Park nostalgic space...) https://ashui.com/mag/chuyenmuc/ quy-hoach-do-thi/4881-cong-vien-khong-gian-goi-nhoqua-khu.html. 